\title{
An Analysis Lexical Cohesion In Jakarta Post News
}

\author{
Muhammad Hasyimsyah Batubara ${ }^{1}$, Cut Dara Ilfa Rahila ${ }^{2}$, Ridaini ${ }^{3}$ \\ ${ }_{1,2,3}$ IAIN Takengon, Aceh Tengah, Aceh, Indonesia \\ ${ }^{1}$ muhammad.hasyimsyahbatubara@gmail.com*; ${ }^{2}$ dara.rahila@gmail.com; ${ }^{3}$ muhammad.hasyimsyahbatubara@gmail.com \\ * corresponding author
}

\section{ARTICLE INFO}

Article history

Received 01 July 2021

Revised 20 September 2021

Accepted 05 November 2021

\section{Keywords}

Keyword_1 Jakarta Post News Keyword_2 Lexical Cohesion Keyword_3 Reportage Keyword_4 Opinion

\begin{abstract}
This research is about lexical cohesion (repetition, synonym, antonym, hyponym, collocation). This study's objectives were: (1) to find the type of LC in the reportage, and opinion column of Jakarta Post News and (2) find the dominant type of LC in the reportage and opinion column of Jakarta Post News. Researchers used library research, while the data sources were the news reports and opinion texts of the Jakarta Post News, which consisted of 30 opinion news and 30 reportage news in edition October. Data analysis used Miles and Huberman's model (reduction, display and verification). The results found synonym 94, repetition 87 , antonym 67 , hyponym 40 , collocation 30 . The total LC in the Jakarta Post News is 318. The dominant LC in the Jakarta Post is synonymous with a total of 94 words.
\end{abstract}

This is an open access article under the CC-BY-SA license.

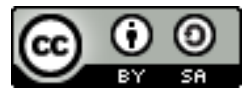

\section{INTRODUCTION}

A language is an essential tool in human activities for communicating with other people in the school, community, and office environment. Language makes it easier for someone to unite perceptions with other people because whatever work we are in requires communicating using the appropriate and correct language. Thus, the position of language cannot be separated from everyday life that occurs now and in the past or the future. In the course of its development, language developed by spawning several parts in language studies. This phenomenon occurs to make it easier for people to learn the language itself. One of the language developments is discourse analysis, and it is a language method for communicating socially and culturally because discourse is formed by a series of related words to communicate with others correctly and adequately.

In discourse analysis, there is lexical cohesion which is intertextual. To make a discourse requires excellent and correct language so that readers can understand the topic or area being discussed. The text is built by arranging the writer's words in conveying ideas and getting interpretations by the readers. Meanwhile, if we talk about the word's context, this is automatically appurtenant to cohesion. Following Halliday and Hasan (1976); Martin (2001) in Malah et al. (2017) stated that LC referring to the linguistic resources that signal discourse relations that transcend grammatical relations. Further, lexical cohesion is for the intercourse in meaning among lexical items in the text, and in distinctive the words of content and the relationships amongst them, each meaning of the content of the discourse, its integrity so that it can be understood by readers and listeners (Paltridge, 2006). So with the continuity between one part of the text and another, it becomes a good language arrangement, and good communication is also established. 
The selection of vocabulary achieves the cohesive effect. That means the selection of vocabulary builds connections in text and makes connections between lexical cohesion and text. Thus, the Jakarta Post newspaper is a relationship between vocabulary and text so that it forms a sentence in the media used by the public which contains news. The reasons for choosing the Jakarta Post review the latest news, political, social, cultural, and educational issues contained in the Jakarta Post column reportage and opinion. Editorial columns by editors are used to address what is happening at the moment so that the issue is worthy of being published, can also be confused with thoughts, goals, views, and criticisms of the editor on issues that are being a hot issue. News writers in the editorial column must use journalistic language, namely the language of mass communication used in magazines, newspapers, television, and radio.

The reason for choosing the Jakarta Post News is to be the research title because the Jakarta Post news is easily found on social media, such as on Facebook, the browser, and the internet. So it is interesting to examine the contents of the news contained in the Jakarta Post in the Lexical Cohesion section. Some previous researchers have already researched it, so it is still interesting to study with new research. The author is interested in analyzing lexical cohesion at the Jakarta Post News because the discourse is written in standard English. The Jakarta Post's editorial text is certainly coherent to understand the editor's intent or attitude well. For that interest, the editorial text is worth reviewing to find out the lexical aspects of cohesion contained within it. More specifically, the author wants to analyze the choice of words in Jakarta Post News column reportage and opinion, which are part of lexical cohesion. Based on the facts just from the facts, an analysis needs to be done as library research. This research will apply the title to analyze lexical cohesion in Jakarta Post News reportage and opinion column.

\section{LITERATURE REVIEW}

\subsection{Lexical Cohesion}

Lexical cohesion is relations between semantics form a discourse by utilizing lexical elements or words (McCarthy, 1991; Nunan, 1993; Untung, 2005; Morley, 2009). Further, lexical cohesion is a type of cohesion where certain lexical features relate sentences to one another in the text (Dahl, 2000; In Rahimi and Ebrahimi, 2012). Lexical cohesion is related to conceptual structure and can signal a relationship between two structures (Haris and Yunus, 2014). A lexical cohesion aspect is a cohesion tool that makes a discourse coherent (Zhao and Zhou, 2009; Moini and Kheirkhah, 2016; Stotsky, 1983; McCarthy et al., 2010; Hoey, 1991 in Al-Ghazalli and Majli, 2019). According to Mulyana (2005: 29), LC is a lexical relationship among parts of the discourse to get cohesive structure harmony. Mulyana revealed that the purpose of using these lexical aspects was to obtain the effect of the intensity of language meaning, clarity of information, and the beauty of other languages (Mulyana, 2005).

Furthermore, Halliday and Hasan (1976) state the LC is the cohesive effect achieved by selecting vocabulary. From another point of view, lexical cohesion resources denote how speakers and writers utilize lexical items to create the text consistently associated with their field (Eggins, 2004:42). In particular, Witte and Faigley (1981: 200) stated that LC is the subcategory that best uncovers the overall writing quality. The leading group of LC are reiteration (repetition, synonymy, antonymy, hyponymy) and collocation (Halliday and Hasan, 1976; Paltridge, 2006).

\subsection{Type of Lexical Cohesion}

By Halliday and Hasan,1976; Rani et al., 2004: 129, lexical cohesion devices consist of reiteration and collocation. Reiteration is a prevalent word that leads back to a lexical 
item, in between, like synonym, repetition, antonymy, meronymy, hyponymy. A synonym is a word that has a similarity in meaning. Repetition is the reduplication of the same word, usually with the same reference (Zaimar and Harahap, 2011: 148). Antonym is the relationship between a different meaning. Hyponymy is a connection between a component with a general meaning named subordinate and a component that specific meaning. Meronymy calls this category co-specification, which includes the link among two items with a common general item (Halliday and Hasan, 1976: 28; Tanskanen, 2006). The second type of lexical cohesion is collocation, which is the stable relationship between words (Halliday and Hasan (1976: 28). Furthermore, collocation is the cohesive force contracted by any pair of lexical items whose meaning is related or associated with lexical items that regularly co-occur (Halliday and Hasan, 1976; Halliday and Hasan 2013 in Antony 2019).

\section{RESEARCH METHODOLOGY}

This research is about lexical cohesion and lexical cohesion types found in Jakarta Post News. The researcher used qualitative research, and the kind of research is library research. According to Sugiyono, the qualitative research system is a research procedure based on postpositivism philosophy, used to verify the condition of normal objects, where the investigator is a crucial instrument, data collection techniques are carried out jointly, data analysis is qualitative inductive, and research results stress more than generalization (Sugiyono, 2017). In this study, the sources used to collect data are the Jakarta Post News and other sources by collecting news reportage texts and opinions in the Jakarta Post to support data search. Researchers will find out about lexical cohesion and lexical cohesion types from the Jakarta Post News, which consists of 30 news opinions and 30 news reportage in the October issue. In analyzing the data, the researchers used Miles and Huberman's model. According to Miles and Huberman (1986), there are three actions in analyzing the data in this model: data reduction, data display, conclusion/verification data.

Some steps of research in this study were as follows:

1. Select a description of the necessary materials from available sources.

2. Examine the index that contains the variables and topics of the problem under investigation.

3. The next thing that becomes more specific is looking for books, articles, and biographies that help get the materials relevant to the problem under study.

4. Select the news that will be the source of data in this case that researchers analyze. Researchers choose news reportage and opinion.

5. Search for news through the website. In this step, researchers only search for the news contents and read to gather news and make it easy to combine and classify the types of lexical cohesion in the news text news reportage and opinion.

6. After relevant information is found, the researchers determine lexical cohesion types in order of importance relevant to the problem. The research process is reading, writing, and classifying lexical cohesion types in the news text news reportage and opinion in the final step.

\section{FINDINGS}

This chapter is divided into main sections, namely research findings and discussion. Research finding presents all findings of lexical cohesion in Jakarta Post News. The data are served with the frequency of reiteration (repetition, synonymy, antonymy, hyponym) and collocation in the news on the Jakarta Post News. 


\subsection{News Opinion}

Based on the explanation from the table above, researchers found lexical cohesion types as though repetition, synonym, antonym, hyponym, and colocation. The above explanation is that the Jakarta Post News found several types of lexical cohesion. In the Jakarta Post news, researchers found 54 repetitions, 71 synonyms, 57 antonyms, 33 hyponyms, and 17 colocations. Total of all 232 types of news contained in the Jakarta Post News Opinion.

Table 1. Total of type of $\mathrm{LC}$ in news opinion

\begin{tabular}{clc}
\hline No & Type of LC & Total \\
\hline 1 & Repetition & 54 \\
2 & Synonym & 71 \\
3 & Antonym & 57 \\
4 & Hyponym & 33 \\
5 & Collocation & 17 \\
\hline & Total & 232 \\
\hline
\end{tabular}

\subsection{News Reportage}

Based on the explanation from the table above, the researcher found lexical cohesion types as though repetition, synonym, antonym, hyponym, and colocation. The above explanation is that the Jakarta Post News found several types of lexical cohesion. In the Jakarta Post news, researchers found 33 repetitions, 23 synonyms, 10 antonyms, 7 hyponyms, and 13 colocations. All 86 types of news contained in the Jakarta Post Reportage.

Table 2. Total of type of LC in news reportage

\begin{tabular}{clc}
\hline No & \multicolumn{1}{c}{ Type of LC } & Total \\
\hline 1 & Repetition & 33 \\
2 & Synonym & 23 \\
3 & Antonym & 10 \\
4 & Hyponym & 7 \\
5 & Collocation & 13 \\
\hline & Total & 86 \\
\hline
\end{tabular}

\subsection{Dominant Kinds of LC Analysis Finding in Reportage and Opinion}

From the above analysis, the researcher can conclude that the word repetition is mainly found in the Jakarta Post News text. The researcher found 94 words that were repeated in the Jakarta Post. Below the data taken from the text of text in Jakarta Post News:

Table 3. Kinds of LC analysis finding in reportage and opinion in Jakarta post news

\begin{tabular}{clc}
\hline No & \multicolumn{1}{c}{ Type of LC } & Total \\
\hline 1 & Repetition & 87 \\
2 & Synonym & 94 \\
3 & Antonym & 67 \\
4 & Hyponym & 40 \\
5 & Collocation & 30 \\
\hline & Total & 318 \\
\hline
\end{tabular}




\section{DISCUSSION}

\section{Synonym}

Based on the above observations, a synonymous lexical cohesion form was found in the Jakarta Post News. It can be concluded that synonyms dominate in the opinion and reportage columns. Based on the above analysis, this study found many repetitions in the Jakarta Post News. In our opinion, 71 words, phrases, or sentences were reported in the opinion column, while in the reportage, there were 23 words, phrases or sentences reported. The total of these two columns is 94 lexical cohesion of synonyms.

2. Repetition

After the data was attached, the researcher verified it to find out the purpose of the study. At this stage, the researcher presents reduction data for analysis of LC types in the Jakarta Post News. Based on the above analysis, this study found many repetitions in the Jakarta Post News, either in the opinion column or the reportage. There are 54 words, phrases, or sentences reported in the opinion column, while in the reportage is 33 words, phrases, or sentences were reported. The total of the opinion and reportage columns was 87 repetition lexical cohesions.

3. Antonym

Based on the observation above, the position of the three lexical cohesion of text in the opinion column and the Jakarta Post News reportage is a form of antonym. The researcher presented reduction data to analyze the type of LC of antonyms in the Jakarta Post News and found that 57 words, phrases, or sentences were reported in the opinion column, while in the reportage are 10 words, phrases, or sentences were reported. The total number of these two columns is 67 lexical cohesion of antonyms.

4. Hyponym

Based on the above analysis, this study found a hyponym of lexical cohesion as many as 33 words, phrases, or sentences reported in the opinion column, while in the Jakarta Post News reportage, there were 7 words, phrases, or sentences that were reported. The total number of these two news columns is as many as 40 hyponyms.

5. Colocation

Based on the above observations, the last position of lexical cohesion in the Jakarta Post News is colocation. Based on the analysis carried out, the study found 17 words, phrases, or sentences in the form of colocation in the opinion column, while in the reportage, there were 13 words, phrases, or sentences found. The number of both was 30 .

\section{CONCLUSION}

The conclusions drawn in this study are that there are five types of LC in this study. The researcher uncovers 87 repetitions, meets 94 synonyms, found 67 antonyms, 40 hyponyms, and the researcher also found 30 collocation from opinion and reportage in the Jakarta Post News. The total LC in the Jakarta Post News is 318. The researcher can conclude that the dominant type of LC in this study is a synonym in the opinion and reportage Jakarta Post News.

\section{REFERENCES}

Antony Somba Mang"oka". (2019). The use of Lexical Cohesion in the English written texts of Hearing Impaired High Students. IOSR Journal of Humanities and Social Science (IOSR-JHSS), 24(10), 25-33. http://DOI: 10.9790/0837-2410022533

Dahl, T. (2000). Text Summarisation: From Human Activity to Computer Program. The Problem of Tacit Knowledge. HERMES - Journal of Language and Communication in Business, 25(2000), 113-131. 
https://doi.org/10.7146/hjlcb.v13i25.25588.

Eggins, S. (2004). An Introduction to Systemic Functional Linguistics. (2nd ed.). New York \& London: Continuum.

Haris, Siti NF dan Melor Md Yunus. (2014). The Use of Lexical Cohesion among TESL Post Graduate Students in Academic Writing. Journal of Education and Human Development, 3(2), 847-869.

http://jehdnet.com/journals/jehd/Vol_3_No_2_June_2014/52.pdf

Halliday, M.A.K and Hasan, R. (1976). Cohesion in English. Harlow: Longman.

Halliday, M. A., \& Hasan, R. (2013). Cohesion in English. New York: Routledge Publishers.

Hoey, M. (1991). Patterns of Lexis in Text. Oxford: Oxford University Press.

Malah, Zubairu., Tan, H., Rashid, S.M., (2017). Evaluating Lexical Cohesion in Nigerian Newspaper Genres: Focus on the Editorials. International Journal of Applied Linguistics \& English Literature, 6(1), 240-256. http://dx.doi.org/10.7575/aiac.ijalel.v.6n.1p.240

Martin, J. R. (2001). Cohesion and Texture. In D. Schiffrin, D. Tannen, \& H. E. Hamilton (Eds.), The Handbook of Discourse Analysis (pp. 35-53). Malden, MA: Blackwell.

McCarthy, M. (1991). Discourse Analysis for Language Teachers. Cambridge: Cambridge University Press.

McCarthy, M., O'Keeffe, A. \& Walsh, S. (2010). Vocabulary Matrix: Understanding, Learning and Teaching. Boston: Cengage Learning.

Mehdi Falih Al-Ghazalli and Noor Majeed Majli. (2019). A Study of Lexical Cohesion in Women's Articles Written by Native and Non-Native Speakers of English. International Journal of English Language and Linguistics Research, 7(1), 1-18. http://www.eajournals.org/wp-content/uploads/A-Study-of-Lexical-Cohesion-inWomen\%E2\%80\%99s-Articles-Written-by-Native-and-Non-Native-Speakers-ofEnglish.pdf

Miles, Matthew. B \& Huberman, M. A. (1984). Qualitative Data Analysis. London: Sage Publication, Inc.

Moini, M. R and Kheirkhah. F. (2016). Use of Cohesive Devices in Children and Regular Literature: Conjunctions and Lexical Cohesion. International Journal of Comparative Literature dan Translation Studies, 4(4), 12-23. https://www.journals.aiac.org.au/index.php/IJCLTS/article/view/2771/2359

Morley, J. (2009). Lexical Cohesion and Rhetorical Structure. In: J. Flowerdew \& M. Mahlberg (eds.). Lexical Cohesion and Corpus Linguistics. (pp. 5-20). Amsterdam: John Benjamins.

Mulyana. (2005). Kajian Wacana: Teori, Metode, dan Aplikasi Prinsip-prinsip Analisis Wacana. Yogyakarta: Tiara Wacana.

Nunan, David. (1993). Introduction English Linguistic. London: Penguin Group.

Paltridge, Brian. (2006). Discourse Analysis. New York. Continuum International Publishing Group.

Rahimi, Ali and Ebrahimi, N. A. (2012). Lexical Cohesion in English and Persian Texts of Novels. Mediterranean Journal of Social Sciences, 3(11), 569-577. http://Doi:10.5901/mjss.2012.v3n11p569

Rani, Abdul, Bustanul Arifin, dan Martutik.2004. Analisis Wacana Sebuah Kajian Bahasa dalam Pemakaian. Malang: Bayumedia Publishing.

Stotsky, S. (1983). Types of Lexical Cohesion in Expository Writing: Implications for Developing the Vocabulary of Academic Discourse. College Composition and Communication, 34(4), 430-446. https://doi.org/10.2307/357899 
Sugiono. (2017). Metode Penelitian, Kuantatif, Kualitatif, Dan R\&D. Bandung: Alfabeta. Tanskanen, S. K. (2006). Collaborating Toward Coherence: Lexical Cohesion in English Discourse. Amsterdam: John Benjamins Publishing Company.

The Jakarta Post. (2018). https://www.thejakartapost.com/. It was accessed on October 19, 2018.

Untung, Yuwono. (2005). Pesona Bahasa Langkah Awal Memahami Linguistik. Jakarta: PT Gramedia Pustaka Utama.

Witte, S. P. \& Faigley, L. (1981). Coherence, Cohesion and Writing Quality. College Composition and Communication, 32(2), 189-204. https://doi.org/10.2307/356693

Zaimar, Okke Kusuma Sumantri dan Ayu Basoeki Harahap. (2011). Telaah Wacana Teori dan Penerapannya. Jakarta: Komodo Books.

Zhao J., Yan W, and Zhou Y. (2009). A Corpus-Based Study of Cohesion in English Medical. Texts and it is Chinese Translation. International Journal of Biomedical Science, 5(3), 313-320.

https://www.ncbi.nlm.nih.gov/pmc/articles/PMC3614791/ 